\title{
A INDÚSTRIA NO DISTRITO DE VISEU (SUBSÍDIOS PARA O SEU ESTUDO)
}

Alberto Martinho

\section{INTRODUÇÃO}

\subsection{Justificação do trabalho}

Quando em Outubro de 1988 fomos contactados pelo Presidente da Associação Industrial da Região de Viseu (AIRV) ${ }^{1}$ para a efectivação de um estudo tendente à caracterização do tecido industrial ${ }^{2}$, respondemos, desde logo, afirmativamente.

Fomos motivados para a realização deste estudo, sobretudo pelas seguintes razões:

- A Universidade Católica Portuguesa (Centro Regional de Viseu), através da sua Associação de Apoio ao Instituto Universitário de Desenvolvimento e Promoção Social (A.I.U.D.P.S.) pretende estar à escuta das necessidades dos actores económicos, culturais e sociais da região, de molde a poder ser parceiro na investigação-acção que possa ser levada a cabo.

- A Universidade Católica está também interessada na formação integral dos alunos. Por tal, aproveita estas oportunidades para a formação, científica e humana, dos elementos que nela trabalham, quer os docentes, quer os discentes.

- Este estudo também deu origem à colaboração com outras instituições que trabalham na área desde o Instituto de Apoio às Pequenas $\mathrm{e}$ Médias Empresas e ao Investimento (IAPMEI), Comissão de Coordenação da Região Centro (CCRC), Empresas, Instituições Bancárias, Câmaras Municipais, entre outras.

Por outro lado aproveitou-se esta oportunidade para a divulgação da AIRV (objectivos da associação, serviços que presta aos associados, etc.), junto de 
potenciais sócios, bem como de empresas já inscritas mas que ainda não tinham tomado conhecimento da nova dinâmica que a animava.

Já depois de iniciado o estudo foram levadas a cabo acções conjuntas integrando elementos da AIRV, da Universidade Católica e do IAPMEI, no sentido da divulgação de apoios inseridos nos Fundos Estruturais Comunitários, sobretudo os dirigidos à indústria em geral e ao turismo, em especial.

\subsection{Metodologia utilizada}

\subsubsection{O âmbito do trabalho}

Tivemos necessidade imediata de definir o universo das empresas existentes e da tipificação das actividades desenvolvidas. Quanto ao primeiro aspecto deparámos com imensas dificuldades, uma vez que se decidiu inquirir não só as empresas do distrito de Viseu, mas também de outros concelhos limítrofes do distrito da Guarda, como Aguiar da Beira, Gouveia, Fornos de Algodres, Seia, Vila Nova de Foz Côa, Trancoso e Oliveira do Hospital do distrito de Coimbra, uma vez que há associados localizados nestas áreas ou pelo menos havia empresários que já tinham contactado a AIRV.

Na AIRV, como é compreensível, não existia a listagem completa. Tentámos as repartições concelhias de finanças. Aqui só deparámos com uma colaboração em casos pontuais, o que dificultou a nossa pesquisa. No contacto com as Câmaras Municipais também apenas obtivemos dados fragmentados. $\mathrm{O}$ mesmo aconteceu com a tentativa realizada junto do IAPMEI e da CCRC. O contacto havido com o Registo Nacional das Pessoas Colectivas revelou-se infrutífero. Foi assim possível elaborar listas de empresas embora incompletas, por concelho, que serviram como primeiro ponto de partida para delinear o âmbito do trabalho.

Em relação ao tipo das actividades desenvolvidas resolvemos optar por considerar, no âmbito do nosso trabalho, as empresas que se inserissem nos Códigos das Actividades Económicas (C.A.E.) 2 e 3.

Uma vez que não foi possível encontrar o universo das empresas inseridas nos referidos códigos resolvemos inquirir a totalidade das empresas existentes.

\subsubsection{A construção do questionário}

Tivemos conhecimento da existência de um estudo em curso na região de Águeda para caracterizar o tecido industrial existente, promovido pela Associação Industrial de Águeda.

Através de contactos havidos foi possível conhecer o questionário aplicado. Da sua análise conclui-se que não se adaptava aos objectivos que norteavam o nosso trabalho, nem à região que constituía o "terreno" do nosso estudo. 
Assim sendo, iniciámos alguns contactos com a CCRC e com o IAPMEI, no sentido de recolher algumas sugestões e comentários ao questionário que íamos construindo. Ao fim de algum tempo foi possível aplicar o questionário-piloto, no fim do qual se procedeu a pequenas alterações.

\subsubsection{A aplicação do questionário}

Procedeu-se numa primeira fase ao recrutamento e selecção de alunos. Numa segunda fase iniciámos a formação dos mesmos, de molde a prepará-los para a acção no terreno. Em seguida constituíram-se equipas, estabeleceram-se áreas de actuação para cada uma delas e procedeu-se à aplicação do questionário por entrevista directa com os inquiridos. Nalguns concelhos foi importante o auxílio que as autarquias locais concederam, como a cedência de viaturas a funcionários que acompanhavam as equipas, para localizarem as empresas.

\subsubsection{O tratamento de dados}

Após a aplicação do questionário seguiu-se um período de codificação das respostas. Foi uma longa e difícil tarefa, uma vez que as questões abertas deram origem a inúmeras e variadas respostas (163 dos casos) que foi necessário reagrupar. Este trabalho teve lugar num período de quatro meses após a aplicação dos referidos questionários.

O primeiro tratamento informático dos dados deu origem a longas listagens, que deram lugar a análises e reflexões conducentes a sínteses posteriormente trabalhadas.

\subsection{Agradecimentos}

Agradecemos, em primeiro lugar, ao Sr. Eng. ${ }^{\circ}$ Jorge Oliveira Dias e aos restantes membros da direcção da AIRV a confiança que depositaram na Universidade Católica para a efectivação deste estudo.

Em seguida agradecemos à nova e actual direcção da AIRV presidida pelo Sr. Joaquim Santos, o carinho que colocaram para que o relatório final pudesse ser apresentado no mais curto espaço de tempo possível. Não podemos deixar de lembrar a colaboração que nos foi prestada pelo IAPMEI (Delagação Regional de Viseu) e pela CCRC, agradecendo todo o empenhamento colocado, sobretudo ao nível da elaboração do questionário.

Às autarquias o nosso reconhecimento pela colaboração prestada. Aos empresários o nosso bem-hajam pelo acolhimento dispensado e pelo precioso tempo que lhes roubámos.

Aos alunos do $3 .^{\circ}$ ano do Curso de Gestão e Desenvolvimento Social da Universidade Católica/Secção de Viseu, de 1988/89 e 1989/90, manifestamos o 
nosso reconhecimento pelo empenhamento na aplicação dos questionários, não podendo deixar de salientar o empenhamento e a dedicação colocada para a execução final deste trabalho, com destaque especial para o Dr. Armando Lacerda e para a Dr. ${ }^{a}$ Graça Ferreira.

\section{BREVE CARACTERIZAÇÃO DO DISTRITO DE VISEU}

\subsection{A População}

No quadro $n .^{\circ} 1$ constata-se o decréscimo da população residente nas décadas de 1960 e 1970 . O censo de 1981 teve um acréscimo de 12853 residentes em relação ao censo de 1970 . Porém, no censo de 1991 constata-se um decréscimo de 22643 residentes em relação ao censo de 1981 e de 9790 em relação ao censo de 1970. O destino destas populações processou-se nas migrações internacionais (sobretudo para França, Alemanha, Luxemburgo e, mais recentemente, para a Suíça) e nas migrações internas (Lisboa e outros centros do Litoral). Entre os censos de 1981 e 1991 apenas se registou um acréscimo de população residente nos concelhos de Oliveira de Frades, Mangualde e Trancoso (quadro n. ${ }^{\circ}$ 2), a que não é alheio o fenómeno da instalação de unidades industriais. $O$ único concelho com uma componente predominantemente agrícola em que se verificou um aumento da população foi o de Moimenta da Beira.

\subsection{A agricultura}

Segundo o recenseamento agrícola de 1979 , era de 74318 o número de produtores individuais existentes no distrito de Viseu (ver quadro $n .^{\circ} 3$ ). Destes, apenas $15071(20,28 \%)$ exerciam a profissão de agricultor a tempo inteiro. Cerca de $90,00 \%$ do total dos produtores actuam por conta própria nas suas explorações. A percentagem da população activa na agricultura , tendo em conta a população agrícola trabalhando na exploração (1979) e a população presente em 1981, era de $43,75 \%$. A propriedade nesta região está bastante fragmentada, originando que a área média por exploração seja de 3,05 ha, distribuída por 8,8 blocos. Tal estrutura de propriedade vai condicionar a produção vegetal e a produção animal. Assim, constatamos no quadro $n .^{\circ} 4$ que o número de cabeças de gado bovino, caprino e ovino, em que a técnica de criação em estabulação não é significativa, a média por exploração é baixa, quando comparada com os países da C.E.E.. $O$ mesmo se pode dizer para o caso dos suínos. A excepção pode ser encontrada na criação de galinhas e produção de ovos. No distrito de Viseu, segundo dados colhidos no I.N.E., havia 333 aviários com um efectivo feminino de 627874 aves. O nível tecnológico é assinalável, uma vez que foi neste distrito que teve 


\section{QUADRO 1}

População residente no Distrito de Viseu

\begin{tabular}{|ccccc|}
\hline Ano & $H$ & $M$ & Total $(N)$ & Total $(\%)$ \\
\hline 1950 & 237114 & 257514 & 494628 & 100,00 \\
1960 & 229463 & 252953 & 482416 & 97,53 \\
1970 & 193640 & 217255 & 410795 & 83,05 \\
1981 & & & $423648\left(^{*}\right)$ & 85,64 \\
1991 & & & $401005\left(^{* *}\right)$ & 81,07 \\
\hline
\end{tabular}

(*) O total da população presente é de 421752 (201082 homens e 220670 mulheres).

(**) O total da população presente é de 386548 (185047 homens e 201501 mulheres).

Fonte: I.N.E., Recenseamentos gerais da população, 1950, 1960, 1970, 1981, 1991 (resultados preliminares).

QUADRO 2

População presente e população residente no Distrito de Viseu

(1981 e 1991)

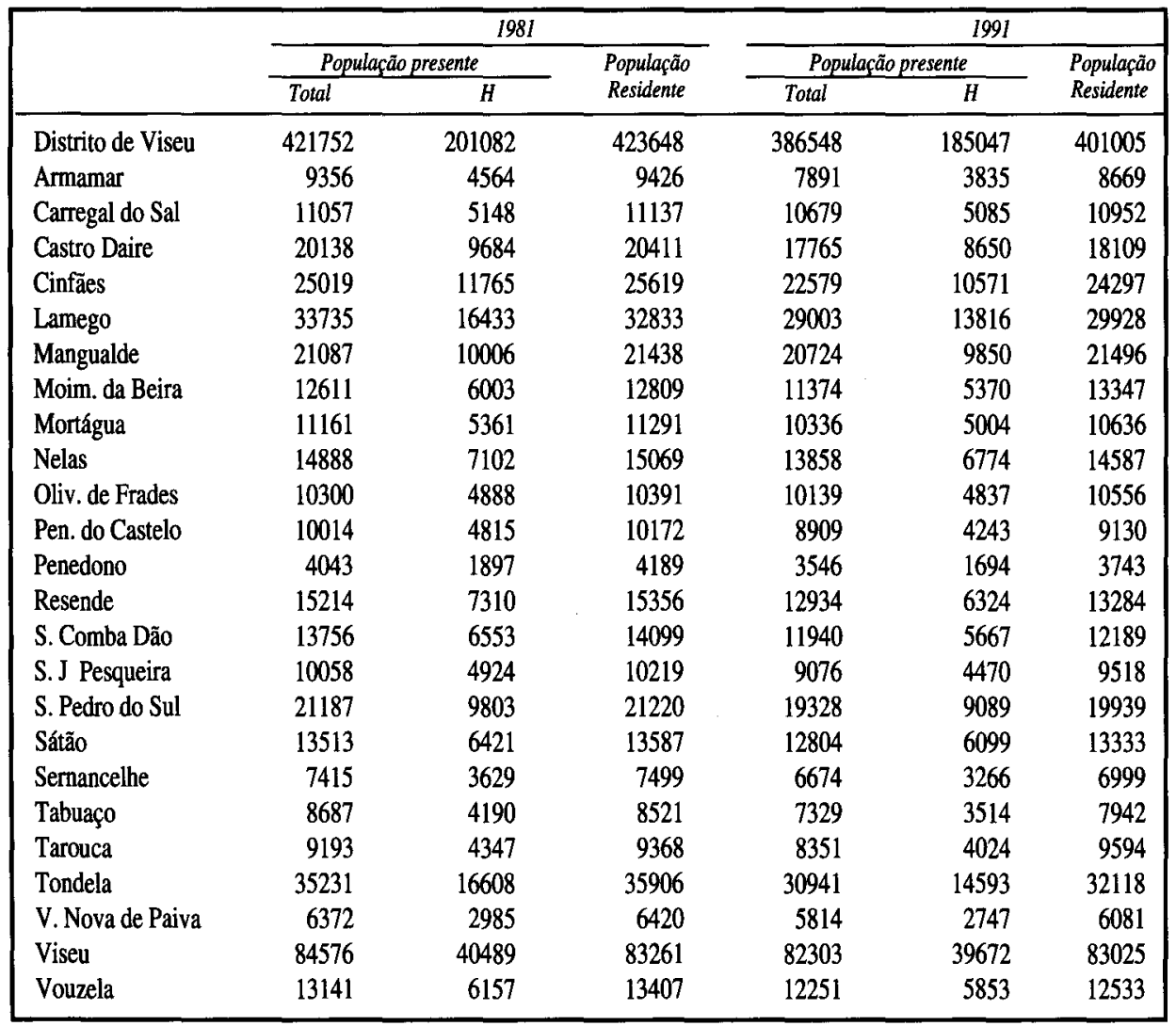

Fonte: I.N.E., Recenseamentos gerais da população, 1981, 1991 (resultados preliminares). 
QUADRO 3

Caracterização agrícola do Distrito de Viseu

1979

Produtores Individuais

74318

Produtores Individuais a Tempo Inteiro

Explorações

74665

Área (HA)

227594

Área Média / Exploração (HA)

3,05

Blocos

658281

Média Blocos / Exploração

8,8

Fonte: I.N.E., Recenseamento agrícola, 1979 (Distrito de Viseu).

\author{
QUADRO 4
}

Caracterização Agrícola do Distrito de Viseu

1979

\begin{tabular}{|lccc|}
\hline & $N^{\bullet}$ de Exploraföes & $N^{\circ}$ de Cabeģas & Média Cab./Exp. \\
\hline Bovinos & 24767 & 59914 & \\
Caprinos & 16880 & 53318 & 2,42 \\
Ovinos & 15920 & 80811 & 3,16 \\
Suínos & 37672 & 114634 & 5,08 \\
\hline
\end{tabular}

Fonte: I.N.E., Recenseamento agricola, 1979 (Distrito de Viseu).

\title{
QUADRO 5
}

Produção das principais culturas agrícolas no Distrito de Viseu

\begin{tabular}{|c|c|c|c|c|c|c|c|c|c|c|}
\hline & \multicolumn{5}{|c|}{1988} & \multicolumn{5}{|c|}{1989} \\
\hline & \multirow{2}{*}{ Super. } & \multirow{2}{*}{ Semente } & \multirow{2}{*}{ Prod. } & \multicolumn{2}{|c|}{ Rendimento } & \multirow{2}{*}{ Super. } & \multirow{2}{*}{ Semente } & \multirow{2}{*}{ Prod. } & \multicolumn{2}{|c|}{ Rendimento } \\
\hline & & & & Porha & Porh & & & & Por/ha & Porth \\
\hline Cereais & 71443 & 4377 & 75159 & 5542 & 87,3 & 73379 & 4507 & 749080 & 6325 & 94 \\
\hline Batata & 11607 & 18573 & 80915 & 6971 & 4,4 & 11723 & 18759 & 95480 & 8145 & 5,1 \\
\hline Vinho & - & - & 297788 & - & - & - & - & 670174 & - & - \\
\hline Total & 83050 & 22950 & 453862 & 12513 & 91,7 & 85102 & 23266 & 840562 & 1447 & 99,1 \\
\hline
\end{tabular}

Fonte: Direcção Regional de Agricultura da Beira Litoral, Coimbra. 
origem a produção industrial de aves, sendo mesmo determinante o seu papel na formação dos preços a nível nacional.

No respeitante ao rendimento das principais produções agrícolas do distrito (quadro ${ }^{\circ}{ }^{\circ}$ 5) também se constata uma média inferior à dos países da C.E.E.

\subsection{A indústria, o comércio e os serviços}

O número total de empresas existentes no distrito de Viseu era de 30830, distribuídas pelas 10 classificações do C.A.E. (Código de Actividades Económicas) (ver quadro n. ${ }^{\circ} 6$ ). Em relação ao volume de emprego, constata-se que o principal empregador é o sector de comércio por grosso e a retalho, restaurantes e hotéis (14465), seguindo-se as indústrias transformadoras com (14873), a construção civil e obras públicas (8584), a agricultura, silvicultura, caça e pesca com (4594), os serviços prestados à colectividade, serviços sociais e serviços pesso-

QUADRO 6

Repartição do N. ${ }^{\circ}$ de Empresas, Volume de Emprego

e Volume de Negócios no Distrito de Viseu, segundo a CAE a um Digito em 1989

\begin{tabular}{|lcrr|}
\hline CAE & N.'de Empresas & NPS & $W N$ \\
\hline 1 & 6856 & 4594 & 16575 \\
2 & 122 & 820 & 2045 \\
3 & 3279 & 14873 & 77591 \\
4 & 5 & 13 & 6 \\
5 & 4298 & 8584 & 15936 \\
6 & 11947 & 14465 & 125963 \\
7 & 756 & 1363 & 6069 \\
8 & 1554 & 768 & 6197 \\
9 & 1964 & 2771 & 6174 \\
10 & 52 & - & - \\
Total & 30830 & 48251 & 256556 \\
\hline
\end{tabular}

Fonte: I.N.E., Estatísticas Industriais, 1989.

DIVISÃO 1 - Agricultura, Silvicultura, Caça e Pesca.

DIVISÃO 2 - Indústrias extractivas.

DIVISÃO 3 - Indústrias transformadoras.

DIVISÃo 4 - Electricidade, gás e água.

DIVISÃO 5 - Construção e obras públicas

DIVISÃO 6 - Comércio por grosso e a retalho, restaurantes e hotéis.

DIVISÃ̃ 7 - Transportes, armazenagens e comunicações.

DIVISÃO 8 - Bancos e outras instituições financeiras, seguros, operações sobre imóveis e serviços prestados às empresas.

DIVISÃO 9 - Serviços prestados à colectividade, serviços sociais e serviços pessoais.

DIVISÃO 10 - Actividades mal definidas. 
ais, com 2771, os transportes, armazenagem e comunicações com 1363, as indústrias extractivas com 820 , os bancos e outras instituições financeiras, seguros, operações sobre imóveis e serviços prestados às empresas com 768 , a electricidade, gás e água com 13.

Em relação ao volume de negócios, constata-se que é o sector de comércio por grosso e a retalho, restaurantes e hotéis o primeiro (125963 contos), seguindo-se as indústrias transformadoras em segundo (77591), a agricultura, silvicultura, caça e pesca em terceiro (16575), a construção civil e obras públicas em quarto (15936), os bancos e outras instituições financeiras, seguros, operações sobre imóveis e serviços prestados às empresas em quinto (6197), os serviços prestados à colectividade, serviços sociais e serviços pessoais em sexto (6174), os transportes, armazenagem e comunicações em sétimo (6069), as indústrias extractivas em oitavo (2045), a electricidade, gás e água em nono (6).

No que respeita ao volume de vendas constata-se que $11742(38,09 \%)$ não realizaram ou não declararam as vendas (ver quadro $\mathrm{n} .{ }^{\circ} 7$ ). Constata-se, no entanto, que $17808(57,77 \%)$ do total realizaram vendas entre 1 a $25.000 .000 \$ 00$. De 25001 a $500.000 .000 \$ 00$, há 1204 (3,91\%) empresas. De 500001 a $20.000 .000 .000 \$ 00$ há $76(0,25 \%)$. Acima deste último escalão não encontramos nenhuma empresa. Constata-se, pois, a predominância de pequenas e médias empresas.

QUADRO 7

Repartição das Empresas do Distrito de Viseu segundo o Escalão do $\mathrm{N}^{\circ}$ de Vendas em 1989

\begin{tabular}{|cc|}
\hline Volume de Vendas (Contos) & N. de Empresas \\
\hline 0 & 11742 \\
1 a 25000 & 17808 \\
25001 a 50000 & 581 \\
50001 a 75000 & 211 \\
75001 a 100000 & 117 \\
100001 a 125000 & 60 \\
125001 a 150000 & 49 \\
150001 a 250000 & 114 \\
250001 a 500000 & 72 \\
500001 a 1000000 & 43 \\
1000001 a 2500000 & 26 \\
2500001 a 5000000 & 6 \\
5000001 a 10000000 & 0 \\
10000001 a 20000000 & 1 \\
20000001 ou mais & 0 \\
\hline
\end{tabular}

Fonte: I.N.E., Estatísticas Industriais, 1989 


\subsection{A População escolar}

Verifica-se nos quadros $n^{\circ} 8 \mathrm{e} 9$ que a cobertura distrital no ensino primário é superior à do pré-primário. A expansão do ensino pré-primário verificou-se sobretudo na década de 1980. A esta expansão não foi alheio o papel das autarquias locais, com o fornecimento de locais de funcionamento e de outras infraestruturas de apoio.

No ensino secundário (quadro 10) assistiu-se nas décadas de 1970 e 1980 a uma expansão do mesmo nível no distrito, com a edificação de novas infraestruturas e criação de novos pólos. A população deste grau de ensino aumentou, verificando-se, presentemente, uma tendência para a estabilização.

$O$ ensino politécnico surgiu nesta última década, estando neste momento a verificar-se o incremento dos cursos. A Universidade Católica instalou-se em Viseu em 1980, sendo frequentadas as quatro licenciaturas actuais por cerca de 1100 alunos.

\section{A EMPRESA}

\subsection{Distribuição geográfica}

Do total das 1093 empresas inquiridas, $154(14,09 \%)^{3}$ situam-se no concelho de Viseu, $70(6,40 \%)$ no de Mangualde, $70(6,40 \%)$ no de São Pedro do Sul, 52 $(4,76 \%)$ no de Nelas, $49(4,48 \%)$ no de Tondela, $49(4,48 \%)$ no de Seia, 39 $(3,57 \%)$ no de São João da Pesqueira, 30 (2,74\%) no de Gouveia, 29 (2,65\%) no de Vouzela, $28(2,56 \%)$ no de Oliveira de Frades, $27(2,47 \%)$ no de Satão, 27 $(2,47 \%)$ no de Trancoso, 26 (2,38\%)no de Tarouca, 25 (2,29\%) no de Santa Comba Dão, $25(2,29 \%)$ no de Sernancelhe, $24(2,20 \%)$ no de Oliveira do Hospital, $23(2,10 \%)$ no de Penalva do Castelo, 21 (1,92\%) no de Vila Nova de Paiva. Entre 0-20 empresas situam-se, por ordem decrescente, os concelhos de Resende, Tabuaço, Cinfães, Armamar, Aguiar da Beira, Fornos de Algodres, Carregal do Sal, Mortágua e Penedono.

\subsection{Data da sua formação}

Das 1093 empresas inquiridas, $470(43,00 \%)^{4}$ foram constituídas entre 1980 $-1989,308(28,18 \%)$ entre $1970-1979,136(12,44 \%)$ entre 1960-1969, 83 (7,59\%) entre 1950-1959, 40 (3,66\%) entre 1940-1949, 12 (1,10\%) entre 1930$-1939,6(0,55 \%)$ entre 1920-1929, $3(0,27 \%)$ entre 1900-1909. Contudo ainda 14 $(1,28 \%)$ responderam que a sua formação se processou entre $1800-1899$. Não responderam à questão $21(1,92 \%)$ das empresas inquiridas. Constata-se que das 1093 empresas, $914(83,62 \%)$ tiveram a sua formação entre $1960-1989$, sendo relevante sobretudo o período 1980-1989, como já acima se mencionou. 
QUADRO 8

Número de Escolas no Ano Lectivo de 1991 / 1992

\begin{tabular}{|c|c|c|c|c|}
\hline Concelhos & Infantários & Escolas & Tele-Escolas & TOTAL \\
\hline Armamar & 8 & 27 & - & 35 \\
\hline Carregal do Sal & 12 & 18 & 1 & 31 \\
\hline Castro Daire & 17 & 65 & 6 & 86 \\
\hline Cinfães & 15 & 54 & 16 & 85 \\
\hline Lamego & 36 & 43 & 12 & 91 \\
\hline Mangualde & 23 & 44 & 3 & 70 \\
\hline Moimenta da Beira & 12 & 33 & - & 45 \\
\hline Mortágua & 13 & 30 & 3 & 46 \\
\hline Nelas & 14 & 20 & - & 34 \\
\hline Oliveira de Frades & 8 & 28 & 4 & 40 \\
\hline Penalva do Castelo & 11 & 22 & 1 & 34 \\
\hline Penedono & 4 & 13 & 1 & 18 \\
\hline Resende & 17 & 34 & 5 & 56 \\
\hline Santa Comba Dão & 16 & 21 & - & 37 \\
\hline S. João da Pesqueira & 13 & 21 & 5 & 37 \\
\hline São Pedro do Sul & 29 & 45 & 8 & 80 \\
\hline Sátão & 17 & 35 & 5 & 57 \\
\hline Sernancelhe & 14 & 21 & - & 35 \\
\hline Tabuaço & 8 & 22 & 1 & 31 \\
\hline Tarouca & 18 & 23 & 1 & 41 \\
\hline Tondela & 19 & 67 & 11 & 97 \\
\hline Vila Nova de Paiva & 8 & 15 & - & 23 \\
\hline Viseu & 38 & 106 & 26 & 169 \\
\hline Vouzela & 12 & 30 & 6 & 48 \\
\hline Total & 382 & 837 & 115 & 1326 \\
\hline
\end{tabular}




\section{QUADRO 9}

Alunos no Pré-primário, Primário, Tele-Escola, do Distrito de Viseu em 1991 / 1992

\begin{tabular}{|c|c|c|c|c|}
\hline Concelhos & Ensino Infantil & Ensino Primário & Tele-Escola & TOTAL \\
\hline Armamar & 153 & 627 & 0 & 780 \\
\hline Carregal do Sal & 184 & 840 & 12 & 1036 \\
\hline Castro Daire & 222 & 1350 & 92 & 1664 \\
\hline Cinfães & 252 & 1983 & 620 & 2855 \\
\hline Lamego & 662 & 2293 & 392 & 3347 \\
\hline Mangualde & 303 & 1531 & 67 & 1901 \\
\hline Moimenta da Beira & 269 & 1003 & 0 & 1272 \\
\hline Mortágua & 175 & 715 & 41 & 931 \\
\hline Nelas & 215 & 1072 & 0 & 1287 \\
\hline Oliveira de Frades & 114 & 812 & 82 & 1008 \\
\hline Penalva do Castelo & 209 & 740 & 16 & 965 \\
\hline Penedono & 64 & 290 & 10 & 364 \\
\hline Resende & 244 & 1092 & 85 & 1421 \\
\hline Santa Comba Dão & 246 & 957 & 0 & 1203 \\
\hline S. João da Pesqueira & 224 & 834 & 137 & 1195 \\
\hline São Pedro do Sul & 420 & 1290 & 332 & 2042 \\
\hline Sátão & 306 & 975 & 120 & 1401 \\
\hline Sernancelhe & 137 & 553 & 0 & 690 \\
\hline Tabuaço & 179 & 728 & 20 & 927 \\
\hline Tarouca & 225 & 777 & 25 & 1027 \\
\hline Tondela & 302 & 2071 & 212 & 2585 \\
\hline Vila Nova de Paiva & 145 & 502 & 0 & 647 \\
\hline Viseu & 703 & 6614 & 733 & 8050 \\
\hline Vouzela & 186 & 739 & 149 & 1074 \\
\hline Total & 6139 & 30388 & 3145 & 39672 \\
\hline
\end{tabular}

QUADRO 10

Alunos no secundário do Distrito de Viseu em 1990/91

\begin{tabular}{|rc|}
\hline Anos escolares & Número de Alunos \\
\hline $77^{\circ}, 8 .^{\circ} \mathrm{e} 9 .^{\circ}$ & 9253 \\
$100^{\circ} \mathrm{e} 11^{\circ}$ & 3631 \\
$12 .^{\circ}$ & 2027 \\
\hline
\end{tabular}


QUADRO 11

Dados sobre a Empresa — Localização, Instalações Fabris

Concelho

(N)

\begin{tabular}{|c|c|c|c|c|c|c|c|c|c|c|c|c|}
\hline & & & & & & LASS & $S D A$ & $A E$ & & & & \\
\hline & 2 & 3 & 3.1 & 3.2 & 3.3 & 3.4 & 3.5 & 3.6 & 3.7 & 3.8 & 3.9 & TOT:* \\
\hline ARMAMAR & 0 & 18 & 9 & 1 & 2 & 0 & 0 & 1 & 0 & 5 & 0 & 18 \\
\hline CARREGAL DO SAL & 0 & 15 & 3 & 2 & 9 & 0 & 0 & 0 & 0 & 1 & 0 & 15 \\
\hline CASTRO DAIRE & 5 & 42 & 12 & 6 & 15 & 0 & 0 & 4 & 0 & 5 & 0 & 47 \\
\hline CINFÃES & 0 & 19 & 5 & 2 & 5 & 0 & 0 & 0 & 0 & 7 & 0 & 19 \\
\hline LAMEGO & 0 & 48 & 21 & 5 & 9 & 3 & 2 & 1 & 0 & 7 & 0 & 48 \\
\hline MANGUALDE & 2 & 68 & 10 & 22 & 10 & 4 & 0 & 4 & 0 & 18 & 0 & 70 \\
\hline MOIMENTA DA BEIRA & 1 & 37 & 7 & 1 & 7 & 0 & 0 & 4 & 1 & 17 & 0 & 38 \\
\hline MORTÁGUA & 0 & 14 & 0 & 2 & 8 & 0 & 0 & 2 & 0 & 2 & 0 & 14 \\
\hline NELAS & 1 & 51 & 13 & 4 & 12 & 1 & 1 & 4 & 1 & 15 & 0 & 52 \\
\hline OLIVEIRA DE FRADES & 0 & 28 & 12 & 2 & 3 & 0 & 1 & 3 & 0 & 7 & 0 & 28 \\
\hline PENALVA DO CASTELO & 1 & 22 & 7 & 5 & 2 & 0 & 1 & 1 & 0 & 4 & 2 & 23 \\
\hline PENEDONO & 0 & 11 & 4 & 3 & 3 & 0 & 0 & 0 & 0 & 1 & 0 & 11 \\
\hline RESENDE & 0 & 20 & 7 & 0 & 4 & 0 & 2 & 1 & 0 & 6 & 0 & 20 \\
\hline SANTA COMBA DÃO & 1 & 24 & 6 & 1 & 12 & 2 & 0 & 2 & 0 & 1 & 0 & 25 \\
\hline SAO JOÃO DA PESQUEIRA & 0 & 39 & 26 & 0 & 3 & 0 & 0 & 0 & 0 & 10 & 0 & 39 \\
\hline SAO PEDRO DO SUL & 0 & 70 & 19 & 5 & 15 & 4 & 2 & 6 & 2 & 17 & 0 & 70 \\
\hline SÁTÃo & 0 & 27 & 5 & 3 & 6 & 0 & 0 & 6 & 0 & 3 & 4 & 27 \\
\hline SERNANCELHE & 2 & 23 & 9 & 0 & 5 & 0 & 0 & 3 & 0 & 6 & 0 & 25 \\
\hline TABUAÇO & 0 & 19 & 5 & 1 & 7 & 0 & 0 & 0 & 0 & 6 & 0 & 19 \\
\hline TAROUCA & 0 & 26 & 12 & 2 & 3 & 1 & 0 & 2 & 4 & 2 & 0 & 26 \\
\hline TONDELA & 1 & 48 & 16 & 1 & 17 & 2 & 3 & 2 & 1 & 6 & 0 & 49 \\
\hline VILA NOVA DE PAIVA & 1 & 20 & 3 & 2 & 7 & 0 & 0 & 1 & 0 & 7 & 0 & 21 \\
\hline VISEU & 3 & 151 & 30 & 20 & 47 & 8 & 8 & 11 & 3 & 24 & 0 & 154 \\
\hline VOUZELA & 0 & 29 & 4 & 4 & 6 & 1 & 1 & 3 & 2 & 8 & 0 & 29 \\
\hline AGUIAR DA BEIRA & 0 & 18 & 7 & 0 & 7 & 0 & 0 & 1 & 2 & 1 & 0 & 18 \\
\hline GOUVEIA & 1 & 29 & 9 & 10 & 6 & 0 & 0 & 2 & 0 & 2 & 0 & 30 \\
\hline FORNOS DE ALGODRES & 1 & 17 & 5 & 1 & 3 & 0 & 2 & 3 & 1 & 2 & 0 & 18 \\
\hline SEIA & 1 & 48 & 12 & 15 & 7 & 3 & 1 & 4 & 0 & 6 & 0 & 49 \\
\hline TRANCOSO & 1 & 26 & 9 & 4 & 6 & 0 & 0 & 4 & 0 & 3 & 0 & 27 \\
\hline VILA NOVA DE FOZ-CÔA & 7 & 33 & 23 & 0 & 4 & 0 & 0 & 0 & 0 & 5 & 1 & 40 \\
\hline OLIVEIRA DO HOSPITAL & 1 & 23 & 7 & 4 & 4 & 0 & 0 & 4 & 2 & 1 & 1 & 24 \\
\hline TOTAL - EMPRESAS & 30 & 1063 & 317 & 128 & 254 & 29 & 24 & 79 & 19 & 205 & 8 & 1093 \\
\hline
\end{tabular}

* O total indicado corresponde à soma dos parciais das colunas 2 e 3.0 mesmo acontece nos quadros, do mesmo 14 tipo, que se seguem. 


\subsection{Natureza jurídica e capital social}

No que concerne à natureza jurídica da empresa, constata-se que das 1093 empresas inquiridas $580(53,06 \%)^{5}$ são em nome individual e $407(37,24 \%)$ são sociedades por quotas. Estas duas formas jurídicas representam $987(90,30 \%)$ das empresas inquiridas. Apenas $26(2,38 \%)$ foram constituídas sob a forma de sociedades anónimas. Sob a forma de cooperativas responderam $37(3,39 \%)$.

Verifica-se contudo que das 1093, $1063(97,26 \%)$ englobam-se nas indústrias transformadoras ${ }^{6}$ e $30(2,74 \%)$ nas indústrias extractivas. Das 1063 empresas que se inserem na divisão das indústrias transformadoras, $317(29,82 \%)$ são da subdivisão de alimentação, bebidas e tabaco, 254 (23,89\%) da subdivisão da madeira e da cortiça, $205(19,29 \%)$ da subdivisão da fabricação de produtos metálicos e de máquinas, equipamento e material de transporte, $128(12,04 \%)$ da subdivisão dos têxteis, do vestuário e do couro, $79(7,43 \%)$ da subdivisão dos produtos minerais não metálicos, com excepção dos derivados de petróleo bruto e de carvão, 29 $(2,73 \%)$ da subdivisão do papel, artes gráficas e edição de publicaçães, 24 $(2,26 \%)$ da subdivisão das químicas, dos derivados de petróleo e de carvão, dos produtos de borracha e de plástico, $19(1,79 \%)$ da subdivisão das metalúrgicas de base e $8(0,75 \%)$ da subdivisão de outras indústrias transformadoras.

Em relação ao capital social constatamos que $416(38,06 \%)^{7}$ das empresas responderam "capital ilimitado". Refira-se que a maior parte destas respostas correspondem a empresas em nome individual. Na data em que foram inquiridas ainda não havia a obrigatoriedade de apresentação de contabilidade organizada. Seguem-se as empresas que declararam possuir entre 1000-9999 contos, 192 $(17,57 \%)$ e $152(13,91 \%)$ que declararam possuir entre $10000-499999$ contos. Entre 500000 e 999999 contos foram declaradas $9(0,82 \%)$ e com 1000000 contos e mais $8(0,73 \%)$. Até 999 contos surgiram $160(14,64 \%)$ das respostas. Não responderam à questão $156(14,27 \%)$ das empresas inquiridas. Constatamos, pois, que o número de empresas com um capital social até 999 contos, mais o número das que declararam possuir um capital ilimitado representam $576(52,69 \%)$ do total.

\subsection{O elemento humano}

\subsubsection{Os sócios}

Da análise efectuada ${ }^{8}$ constata-se: (que corresponderão às empresas em nome individual) $590(53,98 \%)$ das empresas inquiridas declararam possuir um sócio, $202(18,48 \%)$ dois sócios, 97 ( 8,87\%) três sócios, $60(5,49 \%)$ quatro sócios, 52 $(4,76 \%)$ cinco a nove sócios, $16(1,46 \%)$ dez a dezanove sócios, $5(0,46 \%)$ vinte a cento e noventa e nove sócios. Com duzentos e mais sócios surgiram 32 (2,93\%) das respostas. Não responderam à questão $39(3,57 \%)$ das empresas inquiridas. 
QUADRO 12

Dados sobre a Empresa - Ano de formação

(N)

\begin{tabular}{|lrrrrrrrrrrrrr|}
\hline & \multicolumn{10}{c}{ CLASSES DA CAE } \\
& 2 & 3 & 3.1 & 3.2 & 3.3 & 3.4 & 3.5 & 3.6 & 3.7 & 3.8 & 3.9 & TOT. \\
\hline $1800-1899$ & 0 & 14 & 7 & 2 & 1 & 2 & 1 & 0 & 0 & 1 & 0 & 14 \\
$1900-1909$ & 0 & 3 & 3 & 0 & 0 & 0 & 0 & 0 & 0 & 0 & 0 & 3 \\
$1910-1919$ & 0 & 0 & 0 & 0 & 0 & 0 & 0 & 0 & 0 & 0 & 0 & 0 \\
$1920-1929$ & 0 & 6 & 1 & 3 & 2 & 0 & 0 & 0 & 0 & 0 & 0 & 6 \\
$1930-1939$ & 0 & 12 & 3 & 2 & 3 & 2 & 0 & 0 & 0 & 2 & 0 & 12 \\
$1940-1949$ & 0 & 40 & 20 & 4 & 4 & 2 & 1 & 2 & 1 & 6 & 0 & 40 \\
$1950-1959$ & 2 & 81 & 42 & 10 & 14 & 4 & 3 & 1 & 0 & 7 & 0 & 83 \\
$1960-1969$ & 4 & 132 & 50 & 11 & 30 & 6 & 2 & 4 & 2 & 27 & 0 & 136 \\
$1970-1979$ & 10 & 298 & 75 & 24 & 85 & 5 & 4 & 33 & 2 & 70 & 0 & 308 \\
$1980-1989$ & 12 & 458 & 107 & 71 & 110 & 8 & 13 & 38 & 14 & 89 & 8 & 470 \\
NÃO RESPOSTA & 2 & 19 & 9 & 1 & 5 & 0 & 0 & 1 & 0 & 3 & 0 & 21 \\
TOTAL-EMPRESAS & 30 & 1063 & 317 & 128 & 254 & 29 & 24 & 79 & 19 & 205 & 8 & 1093 \\
\hline
\end{tabular}

QUADRO 13

Dados sobre a Empresa - Natureza Jurídica

(N)

CLASSES DA CAE

$\begin{array}{llllllllllll}2 & 3 & 3.1 & 3.2 & 3.3 & 3.4 & 3.5 & 3.6 & 3.7 & 3.8 & 3.9 & \text { TOT. }\end{array}$

$\begin{array}{lllllllllllll}\text { EMPRESA PÚBLICA } & 0 & 2 & 1 & 0 & 0 & 0 & 0 & 0 & 0 & 1 & 0 & 2\end{array}$

$\begin{array}{lllllllllllll}\text { EMP. EM NOME INDIVIDUAL } & 11 & 569 & 160 & 44 & 143 & 9 & 8 & 35 & 10 & 156 & 4 & 580\end{array}$ $\begin{array}{lllllllllllll}\text { SOCIEDADE ANÓNIMA } & 2 & 24 & 12 & 5 & 4 & 0 & 0 & 1 & 0 & 2 & 0 & 26\end{array}$ $\begin{array}{lllllllllllll}\text { SOCIEDADE POR QUOTAS } & 16 & 391 & 93 & 72 & 98 & 17 & 16 & 41 & 9 & 41 & 4 & 407\end{array}$ $\begin{array}{lllllllllllll}\text { COOPERATIVA } & 0 & 37 & 32 & 5 & 0 & 0 & 0 & 0 & 0 & 0 & 0 & 37\end{array}$ $\begin{array}{lllllllllllll}\text { SOC. EM NOME COLECTIVO } & 1 & 12 & 7 & 0 & 2 & 0 & 0 & 1 & 0 & 2 & 0 & 13\end{array}$ $\begin{array}{lllllllllllll}\text { OUTRAS } & 0 & 10 & 4 & 2 & 1 & 3 & 0 & 0 & 0 & 0 & 0 & 10\end{array}$ $\begin{array}{lllllllllllll}\text { NAO RESPOSTA } & 0 & 18 & 8 & 0 & 6 & 0 & 0 & 1 & 0 & 3 & 0 & 18\end{array}$ $\begin{array}{lllllllllllll}\text { TOTAL-EMPRESAS } & 30 & 1063 & 317 & 128 & 254 & 29 & 24 & 79 & 19 & 205 & 8 & 1093\end{array}$ 


\subsubsection{Os sócios activos}

A esta questão $416(42,18 \%)^{9}$ das empresas não responderam. No entanto 416 $(38,06 \%)$ responderam possuir apenas um sócio activo, $132(12,08 \%)$ dois sócios activos, $50(4,57 \%)$ três sócios activos, $21(1,92 \%)$ quatro sócios activos, 9 $(0,82 \%)$ cinco sócios activos, $4(0,37 \%)$ seis ou mais sócios activos.

Conclui-se que nas empresas em nome individual nem todos os donos são activos, bem como nas empresas com dois sócios. Nas empresas com três ou quatro sócios esta tendência também se verifica. Nas empresas com cinco e mais sócios é compreensível que tal aconteça, quer se trate de sociedades por quotas ou de sociedades anónimas.

\subsubsection{Os directores}

Relativamente à questão dos directores 839 (76,76\%) não responderam. Tendo em conta que a pergunta possibilitava mais do que uma resposta, constata-se que ainda são relativamente poucas as empresas que possuem especificamente esta função. ${ }^{10}$ Assim $138(12,63 \%)$ das empresas responderam possuir um director, $72(6,59 \%)$ dois directores, $24(2,20 \%)$ três directores, $10(0,91 \%)$ quatro directores, $5(0,46 \%)$ cinco directores, $5(0,46 \%)$ seis directores.

Em relação à especialização ou não dos directores, verificamos ${ }^{11}$ que $197(18.02 \%)$ desempenhavam o cargo de director-geral, $107(9,79 \%)$ de director financeiro, $102(9,33 \%)$ de director comercial, $77(7,04 \%)$ de director fabril, $59(5,40 \%)$ de director técnico e $37(3,39 \%)$ de director de exportação, havendo $20(1,83 \%)$ que não especificaram a função.

Embora a pergunta admitisse mais do que uma resposta, constata-se que é na função de director geral que mais se faz sentir o cargo de director, quando este existe, logo seguida de director financeiro. Esta tendência poderá ser justificada pelo tecido empresarial existente, constituído sobretudo por pequenas e médias empresas.

\subsubsection{Número de trabalhadores}

Das 1093 empresas inquiridas, $476(43,55 \%)^{12}$ declararam possuir entre 1 - 4 trabalhadores, sendo a maior parte das respostas representadas pelas empresas em nome individual. Entre 5-9 trabalhadores responderam $219(20,04 \%)$, entre $10-49$ trabalhadores $285(26,08 \%)$, entre $50-99$ trabalhadores $50(4,57 \%)$, entre 100-199 trabalhadores $18(1,65 \%)$, entre 200-499 trabalhadores responderam 9 $(0,82 \%)$. Com 500 e mais trabalhadores responderam $8(0,73 \%)$. Apenas 28 $(2,56 \%)$ das empresas não responderam a esta questão. Constata-se que 695 $(63,59 \%)$ das empresas empregam de 1-9 trabalhadores.

Verifica-se que as empresas com maior volume de emprego e que possuem entre 1-4 trabalhadores se situam nos subsectores da alimentação, bebidas e 
QUADRO 14

Dados sobre a Empresa - Capital Social

(contos)

(N)

\begin{tabular}{|c|c|c|c|c|c|c|c|c|c|c|c|c|}
\hline & \multicolumn{12}{|c|}{ CLASSES DA CAE } \\
\hline & 2 & 3 & 3.1 & 3.2 & 3.3 & 3.4 & 3.5 & 3.6 & 3.7 & 3.8 & 3.9 & TOT. \\
\hline-199 & 0 & 22 & 8 & 2 & 5 & 2 & 0 & 0 & 0 & 5 & 0 & 22 \\
\hline $200-499$ & 4 & 77 & 27 & 5 & 19 & 5 & 1 & 7 & 1 & 11 & 1 & 81 \\
\hline $500-999$ & 1 & 56 & 12 & 6 & 12 & 3 & 1 & 10 & 3 & 9 & 0 & 57 \\
\hline $1000-9999$ & 6 & 186 & 45 & 31 & 51 & 7 & 5 & 17 & 5 & 23 & 2 & 192 \\
\hline $10000-499999$ & 8 & 144 & 43 & 35 & 31 & 2 & 10 & 8 & 1 & 14 & 0 & 152 \\
\hline $500000-999999$ & 0 & 9 & 5 & 2 & 0 & 0 & 0 & 0 & 0 & 2 & 0 & 9 \\
\hline $1000000-$ & 1 & 7 & 3 & 1 & 2 & 0 & 0 & 1 & 0 & 0 & 0 & 8 \\
\hline CAPITAL ILIMITADO & 6 & 410 & 115 & 35 & 105 & 10 & 5 & 25 & 5 & 105 & 5 & 416 \\
\hline NÃO RESPOSTA & 4 & 152 & 59 & 11 & 29 & 0 & 2 & 11 & 4 & 36 & 0 & 156 \\
\hline TOTAL - EMPRESAS & 30 & 1063 & 317 & 128 & 254 & 29 & 24 & 79 & 19 & 205 & 8 & 1093 \\
\hline
\end{tabular}

QUADRO 15

Dados sobre a Empresa — Número de Sócios

(N)

\begin{tabular}{|lrrrrrrrrrrrrrr|}
\hline & \multicolumn{10}{c}{ CrASSES DA CAE } \\
& 2 & 3 & 3.1 & 3.2 & 3.3 & 3.4 & 3.5 & 3.6 & 3.7 & 3.8 & 3.9 & TOT. \\
\hline 1 & 11 & 579 & 164 & 44 & 146 & 9 & 8 & 36 & 10 & 158 & 4 & 590 \\
2 & 7 & 195 & 38 & 36 & 51 & 10 & 6 & 22 & 5 & 25 & 2 & 202 \\
3 & 6 & 91 & 25 & 19 & 24 & 1 & 4 & 7 & 2 & 8 & 1 & 97 \\
4 & 1 & 59 & 16 & 10 & 14 & 2 & 3 & 7 & 2 & 4 & 1 & 60 \\
$5-9$ & 4 & 48 & 16 & 10 & 8 & 3 & 3 & 3 & 0 & 5 & 0 & 52 \\
$10-19$ & 0 & 16 & 7 & 5 & 2 & 0 & 0 & 2 & 0 & 0 & 0 & 16 \\
$20-199$ & 0 & 5 & 4 & 0 & 0 & 0 & 0 & 0 & 0 & 1 & 0 & 5 \\
$200-$ & 0 & 32 & 31 & 0 & 0 & 0 & 0 & 0 & 0 & 1 & 0 & 32 \\
NÃO RESPOSTA & 1 & 38 & 16 & 4 & 9 & 4 & 0 & 2 & 0 & 3 & 0 & 39 \\
\multicolumn{1}{c}{ TOTAL-EMPRESAS } & 30 & 1063 & 317 & 128 & 254 & 29 & 24 & 79 & 19 & 205 & 8 & 1093 \\
\hline
\end{tabular}


tabaco, fabricação de produtos metálicos e de máquinas, equipamentos e material de transporte, bem como no das madeiras e da cortiça.

Como já referimos, é mais nesta área que se situam as empresas em nome individual.

Contudo verifica-se que são estes três subsectores, acrescidos dos têxteis, do vestuário e do couro que polarizam o maior volume de emprego nas empresas com 100 e mais trabalhadores.

QUADRO 16

Dados sobre a Empresa - Número de Ścios activos

(N)

\begin{tabular}{|lrrrrrrrrrrrr|}
\hline & \multicolumn{11}{c|}{ CLASSES DA CAE } \\
& 2 & \multicolumn{1}{c|}{3} & 3.1 & 3.2 & 3.3 & 3.4 & 3.5 & 3.6 & 3.7 & 3.8 & 3.9 & TOT. \\
\hline 1 & 6 & 410 & 105 & 48 & 109 & 13 & 5 & 30 & 4 & 93 & 3 & 416 \\
2 & 5 & 127 & 25 & 20 & 30 & 6 & 7 & 15 & 4 & 18 & 2 & 132 \\
3 & 4 & 46 & 11 & 12 & 7 & 2 & 2 & 4 & 1 & 6 & 1 & 50 \\
4 & 1 & 20 & 8 & 5 & 1 & 0 & 2 & 1 & 1 & 2 & 0 & 21 \\
5 & 1 & 8 & 2 & 2 & 3 & 0 & 0 & 1 & 0 & 0 & 0 & 9 \\
$>=6$ & 0 & 4 & 0 & 3 & 0 & 0 & 0 & 0 & 0 & 1 & 0 & 4 \\
NÃORESPOSTA & 13 & 448 & 166 & 38 & 104 & 8 & 8 & 28 & 9 & 85 & 2 & 461 \\
$\quad$ TOTAL-EMPRESAS & 30 & 1063 & 317 & 128 & 254 & 29 & 24 & 79 & 19 & 205 & 8 & 1093 \\
\hline
\end{tabular}

QUADRO 17

Dados sobre a Empresa - Número de Directores

(N)

\begin{tabular}{|lrrrrrrrrrrrrr|}
\hline & \multicolumn{11}{c|}{ CLASSES DA CAE } \\
\hline 1 & 2 & \multicolumn{1}{c|}{3} & 3.1 & 3.2 & 3.3 & 3.4 & 3.5 & 3.6 & 3.7 & 3.8 & 3.9 & TOT. \\
\hline & 3 & 135 & 46 & 22 & 27 & 3 & 3 & 12 & 6 & 14 & 2 & 138 \\
3 & 1 & 71 & 22 & 20 & 9 & 2 & 3 & 9 & 0 & 6 & 0 & 72 \\
4 & 1 & 23 & 9 & 3 & 4 & 0 & 3 & 1 & 2 & 1 & 0 & 24 \\
5 & 0 & 10 & 1 & 4 & 2 & 0 & 1 & 0 & 1 & 1 & 0 & 10 \\
6 & 0 & 5 & 2 & 1 & 0 & 0 & 0 & 1 & 0 & 1 & 0 & 5 \\
7 & 0 & 5 & 1 & 2 & 1 & 0 & 0 & 0 & 0 & 1 & 0 & 5 \\
8 & 0 & 0 & 0 & 0 & 0 & 0 & 0 & 0 & 0 & 0 & 0 & 0 \\
9 & 0 & 0 & 0 & 0 & 0 & 0 & 0 & 0 & 0 & 0 & 0 & 0 \\
NÃ0 RESPOSTA & 0 & 0 & 0 & 0 & 0 & 0 & 0 & 0 & 0 & 0 & 0 & 0 \\
TOTAL-EMPRESAS & 25 & 814 & 236 & 76 & 211 & 24 & 14 & 56 & 10 & 181 & 6 & 839 \\
& 30 & 1063 & 317 & 128 & 254 & 29 & 24 & 79 & 19 & 205 & 8 & 1093 \\
\hline
\end{tabular}


QUADRO 18

Dados sobre a Empresa - Directores

(N)

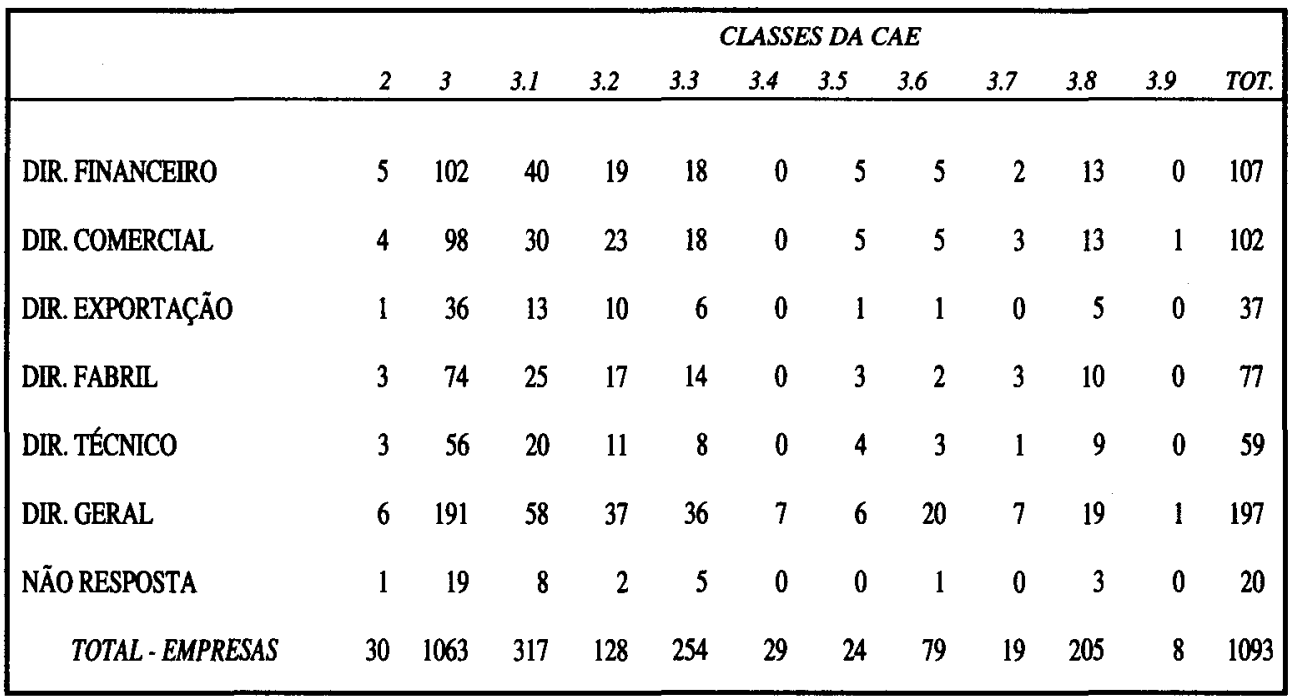

QUADRO 19

Dados sobre a Empresa - Número de Trabalhadores

(N)

\begin{tabular}{|lrrrrrrrrrrrrr|}
\hline & \multicolumn{10}{c|}{ CLASSES DA CAE } \\
& 2 & 3 & 3.1 & 3.2 & 3.3 & 3.4 & 3.5 & 3.6 & 3.7 & 3.8 & 3.9 & TOT. \\
\hline $1-4$ & 5 & 471 & 124 & 32 & 110 & 6 & 6 & 28 & 12 & 147 & 6 & 476 \\
$5-9$ & 10 & 209 & 76 & 9 & 54 & 10 & 6 & 25 & 4 & 24 & 1 & 219 \\
$10-49$ & 13 & 272 & 81 & 51 & 74 & 9 & 10 & 22 & 1 & 23 & 1 & 285 \\
$50-99$ & 1 & 49 & 15 & 15 & 9 & 2 & 0 & 3 & 2 & 3 & 0 & 50 \\
$100-199$ & 0 & 18 & 5 & 10 & 0 & 0 & 1 & 0 & 0 & 2 & 0 & 18 \\
$200-499$ & 0 & 9 & 4 & 5 & 0 & 0 & 0 & 0 & 0 & 0 & 0 & 9 \\
$>=500$ & 0 & 8 & 4 & 3 & 0 & 0 & 0 & 0 & 0 & 1 & 0 & 8 \\
NÃO RESPOSTA & 1 & 27 & 8 & 3 & 7 & 2 & 1 & 1 & 0 & 5 & 0 & 28 \\
\multicolumn{1}{c}{ TOTAL-EMPRESAS } & 30 & 1063 & 317 & 128 & 254 & 29 & 24 & 79 & 19 & 205 & 8 & 1093 \\
\hline
\end{tabular}




\subsection{As instalações e o equipamento}

Das 1093 empresas inquiridas, $301(27,54 \%)$ possuem instalações entre 100$-249 \mathrm{~m} 2$. Entre 1-249 m2 de área ocupada pelas instalações encontram-se 534 $(48,86 \%)$ das empresas. Entre 250-999 m2 responderam $249(22,78 \%)$ das empresas. Entre 1000-2499 m2 responderam $127(11,62 \%)$ das empresas. Entre $2500-4999 \mathrm{~m} 2$ responderam 51 (4,67\%) das empresas. Entre 5000-9999 m2 responderam $34(3,11 \%)$ das empresas. Com mais de $10000 \mathrm{~m} 2$ responderam 28 $(2,56 \%)$ das empresas. Apenas $70(6,40 \%)$ das empresas não responderam a esta questão.

Em relação a uma possível expansão das instalações, $373(34,13 \%)$ das empresas responderam que não possuem espaço para efectivar essa expansão, $335(30,65 \%)$ responderam que possuem espaço suficiente e $339(31,02 \%)$ responderam que possuem bastante espaço. Não responderam a esta questão 46 $(4,21 \%)$ das empresas.

No que concerne à idade da maquinaria, $364(33,30 \%)^{13}$ declararam que esta possui entre 0-4 anos, $276(25,25 \%)$ entre 5-9 anos, $212(19,40 \%)$ entre 10-14 anos, $89(8,14 \%)$ entre $15-19$ anos e $178(16,29 \%)$ possuem mais de 20 anos. Não responderam à questão $280(25,62 \%)$ das empresas inquiridas. Em relação à procedência da referida maquinaria, $545(49,86 \%)^{14}$ das empresas indicaram que era de origem nacional, $315(28,82 \%)$ mencionaram que era estrangeira. Não responderam a esta questão $398(36,41 \%)$ das empresas.

\subsection{A produção}

\subsubsection{Produtos principais}

Das 1093 empresas inquiridas $30(2,74 \%)^{15}$ desenvolveram a sua produção no sector das indústrias extractivas. As restantes situam-se no sector das indústrias transformadoras. No que concerne às primeiras, são a gama dos granitos, xistos, quartzos, areias, britas e extracção de águas que constituem o objecto de produção, com destaque especial para os granitos.

$\mathrm{Na}$ indústria transformadora responderam à questão $1063(97,26 \%)$ das empresas. Neste sector surgem em primeiro lugar $114(10,72 \%)$ das empresas que fabricam pão, $88(8,28 \%)$ que produzem artigos em ferro, com destaque especial para as janelas, portas, portões, caixilharias, $67(6,30 \%)$ que fabricam gradeamentos, marquises, expositores, caixilharia de alumínio; 63 (5,93\%) laboram madeiras-exóticas para exportação e madeiras nacionais para a construção civil; $55(5,17 \%)$ produzem portas de alumínio; $52(4,89 \%)$ produzem móveis de cozinha; $51(4,80 \%)$ produzem mobiliário: móveis diversos de sala, móveis de quarto; $47(4,42 \%)$ produzem artesanato, especialmente olaria, $46(4,33 \%)$ também produzem artesanato, em especial sandálias, sacos e outros artigos similares; $46(4,33 \%)$ produzem azeite em lagares, $42(3,95 \%)$ produzem artigos de confei- 
taria/pastelaria; $36(3,39 \%)$ produzem gradeamentos; $35(3,29 \%)$ produzem artigos em madeira: forro, soalho, rodapés, aros, parquet, pranchas, caixotes, caixilharia, caibros, ripas; $29(2,73 \%)$ situam-se na área de produção de tipografia, artes gráficas, cartazes, serviços postais, jornais; $28(2,63 \%)$ produzem blocos de cimento, manilhas; $27(2,54 \%)$ produzem mármores/campas, jazigos, peitoris e artigos diversos; $27(2,54 \%)$ produzem vinhos; $26(2,45 \%)$ produzem fatos para senhora, confecções para senhora; 25 (2,35\%) produzem calças; 21 (1,98\%) produzem paletes, estilhas; $20(1,88 \%)$ produzem aguardente, aguardente velha; 19 $(1,79 \%)$ produzem casacos, saias, calções, camisas; 18 (1,69\%) produzem fatos para homem, confecções para homem; $17(1,60 \%)$ produzem artefactos de cimento; $16(1,51 \%)$ transformam granitos, chapas de granito, mosaicos, pedra;

\author{
QUADRO 20
}

Dados sobre a Empresa - Equipamento

Maquinaria mais significativa - Idade

(N)

\begin{tabular}{|lrrrrrrrrrrrrr|r|}
\hline & \multicolumn{10}{c|}{ CLASSES DA CAE } \\
& 2 & 3 & 3.1 & 3.2 & 3.3 & 3.4 & 3.5 & 3.6 & 3.7 & 3.8 & 3.9 & TOT. \\
\hline $0-4$ & 7 & 357 & 100 & 44 & 89 & 10 & 9 & 29 & 9 & 65 & 2 & 364 \\
$5-9$ & 7 & 269 & 91 & 18 & 81 & 5 & 4 & 20 & 7 & 43 & 0 & 276 \\
$10-14$ & 11 & 201 & 60 & 12 & 56 & 5 & 4 & 14 & 2 & 48 & 0 & 212 \\
$15-19$ & 5 & 84 & 27 & 9 & 22 & 4 & 0 & 6 & 1 & 15 & 0 & 89 \\
$>=20$ & 3 & 175 & 79 & 8 & 42 & 15 & 1 & 1 & 1 & 28 & 0 & 178 \\
NÃ0 RESPOSTA & 8 & 272 & 58 & 52 & 56 & 8 & 8 & 23 & 5 & 56 & 6 & 280 \\
\multicolumn{1}{c}{ TOTAL-EMPRESAS } & 30 & 1063 & 317 & 128 & 254 & 29 & 24 & 79 & 19 & 205 & 8 & 1093 \\
\hline
\end{tabular}

QUADRO 21

Dados sobre a Empresa — Subcontratação

(N)

\begin{tabular}{|lrrrrrrrrrrrr|r|}
\hline & \multicolumn{110}{c|}{ CLASSES DA CAE } \\
& 2 & 3 & 3.1 & 3.2 & 3.3 & 3.4 & 3.5 & 3.6 & 3.7 & 3.8 & 3.9 & TOT. \\
\hline SIM & 1 & 65 & 8 & 22 & 12 & 3 & 2 & 5 & 4 & 9 & 0 & 66 \\
NAO & 16 & 538 & 157 & 62 & 126 & 21 & 13 & 40 & 7 & 107 & 5 & 554 \\
NÃO RESPOSTA & 13 & 460 & 152 & 44 & 116 & 5 & 9 & 34 & 8 & 89 & 3 & 473 \\
$\quad$ TOTAL - EMPRESAS & 30 & 1063 & 317 & 128 & 254 & 29 & 24 & 79 & 19 & 205 & 8 & 1093 \\
\hline
\end{tabular}


$16 \%(1,51 \%)$ produzem malhas exteriores; $15(1,41 \%)$ produzem mobiliário para a construção civil; $15(1,41 \%)$ produzem madeiras serradas; $14(1,32 \%)$ produzem ferramentas e alfaias agrícolas; $11(1,03 \%)$ produzem vinho do Porto e vinho generoso; $11(1,03 \%)$ produzem travessas em madeira para os caminhos de ferro; $11(1,03 \%)$ produzem queijo, manteiga, requeijão, queijo da serra; 11 $(1,03 \%)$ produzem peças em lata, latão, objectos para o fabrico de queijo, cântaros, regadores, recipientes, ferragens, funilaria, materiais decorativos; $11(1,03 \%)$ produzem estruturas metálicas, coberturas, portas rolantes; $10(0,94 \%)$ produzem pintos, frangos para abate ou frangos abatidos; $10(0,94 \%)$ produzem fios têxteis cardados, tecidos, fios para tricot; $10(0,94 \%)$ produzem artigos diversos de carpintaria.

Verifica-se que, enquanto nas indústias extractivas houve seis ramos diferentes de exploração, na indústria transformadora surgiram cento e noventa e três.

\subsubsection{Produtos secundários}

No que concerne às 30 empresas extractivas constata-se que apenas 8 declararam produzir artigos para além dos principais: aparas para passeios e pavimentos dos granitos e mármores, areias, lages, artefactos de cimento, lareiras e fogões de sala.

Das 1063 empresas transformadoras, $682(64,16 \%)$ responderam que não produziam quaisquer produtos secundários. Das que fabricam produtos secundários, $82(7,71 \%)$ dizem respeito a serrim, serradura, fita para aviários (derivados das madeiras); 49 (4,61\%) cascas, corcódoas, lenha (derivados das madeiras); 29 $(2,73 \%)$ bagaço de vinho e de azeitona, $16(1,51 \%)$ partes de frango; $15(1,41 \%)$ pastelaria, bolo de azeite, bolo-rei, pão-de-ló, folar da Páscoa, bolos secos, tortas e bolos; $14(1,32 \%)$ madeiras-ripas, caibros para a construção civil; $11(1,03 \%)$ artefactos de cimento. Embora a representatividade quantitativa não seja significativa, mencionamos, no entanto, que o número de empresas que fabricam produtos secundários se distribui por 156 variedades.

\subsubsection{Prestação de serviços}

Das 30 empresas extractivas, 21 (70,00\%) não responderam a esta questão. As empresas que responderam afirmativamente englobam-se na instalação e aluguer de máquinas, aplicação de produtos diversos (alcatifas, móveis), terraplanagens. No sector das indústrias transformadoras $261(24,55 \%)$ responderam que também prestavam serviços. Das que responderam afirmativamente $54(5,08 \%)$ declararam aplicar produtos diversos (alcatifas, móveis, entre outros), 37 $(3,48 \%)$ situam-se na área das reparações, assistência e na manutenção, 35 $(3,29 \%)$ na prestação de serviços a outras empresas, a particulares e aos sócios, $33(3,10 \%)$ serrações prestando serviços a outrém, $18(1,69 \%)$ prestam serviços como moagem de azeitonas para o fabrico de azeite, $14(1,32 \%)$ produzem deca- 
pagens e metalização de peças. Também nesta rubrica encontramos 55 variedades de serviços prestados.

\subsubsection{A subcontratação}

Relativamente a esta questão, $66(6,04 \%)^{16}$ das empresas inquiridas responderam possuir contratos de subcontratação com outras empresas; $554(50,69 \%)$ responderam não e $473(43,28 \%)$ não responderam.

No que respeita aos produtos subcontratados verifica-se que existem 44 espécies. Destas, $8(0,73 \%)$ referem-se a camisas, saias, calças, fatos e casacos; 6 $(0,55 \%)$ dizem respeito a vestuário para homem, senhora e criança; $4(0,37 \%)$ referem-se a material em lata e latão; $3(0,27 \%)$ dizem respeito a móveis para aparelhagens; $3(0,27 \%)$ dizem respeito a torneados, $3(0,27 \%)$ respeitam a madeira serrada. Passando para os escalões inferiores, temos $2(0,18 \%)$ que declararam impressão em alumínio; $2(0,18 \%)$ transportes; $2(0,18 \%)$ adornos de campas, jarras, imagens; $2(0,18 \%)$ rolhas; $2(0,18 \%)$ garrafas; $2(0,18 \%)$ rótulos, embalagens. Nas restantes espécies constata-se que a existência de produtos dos ramos das madeiras, da metalomecânica, das malhas e tecidos são as mais representativas.

No que se refere aos mercados, $15(1,37 \%)$ declararam Viseu, $9(0,82 \%)$ Porto, $4(0,37 \%)$ Águeda, $4(0,37 \%)$ Mangualde, $4(0,37 \%)$ Oliveira do Hospital, $4(0,37 \%)$ Região Norte, $3(0,27 \%)$ Tondela, $2(0,18 \%)$ Braga, $2(0,18 \%)$ Belmonte, $2(0,18 \%)$ Lisboa, $2(0,18 \%)$ Leiria, $2(0,18 \%)$ Marinha Grande.

No que concerne ao estrangeiro surgem $5(0,46 \%)$ que responderam a França, $4(0,37 \%)$ a Espanha, havendo $1(0,09 \%)$ de respostas respectivamente para a Alemanha, Inglaterra, Luxemburgo, Suíça. Para Portugal, como um todo, surgem $15(1,37 \%)$ de respostas.

Relativamente ao volume de vendas das empresas com contratos de subcontratação, $21(1,92 \%)$ do total das 1093 empresas inquiridas responderam que estes contratos representam entre $10-24 \%$ das suas vendas totais, $11(1,01 \%)$ responderam que representavam menos de $9 \%, 5(0,46 \%)$ responderam que representavam entre $25-49 \%, 5(0,46 \%)$ responderam que representavam $50-99 \%$. Apenas $3(0,27 \%)$ responderam que representavam $100 \%$ das vendas.

Causas que originaram a subcontratação: $21(1,92 \%)$ das empresas indicaram o excesso de encomendas, a falta de capacidade produtiva; $19(1,74 \%)$ a falta de equipamento, de maquinaria para o produto, a falta de capacidade para produzir determinados produtos ou serviços; $7(0,64 \%)$ é mais rápida e mais barata devido à especialização, menos encargos; $5(0,46 \%)$ a empresa não tem estrutura para esse tipo de serviços; $5(0,46 \%)$ menos riscos de pessoal, menos encargos; 5 $(0,46 \%)$ maior poder negocial, $3(0,27 \%)$ pequena dimensão da empresa, 3 $(0,27 \%)$ inexistência de técnicos na zona, falta de pessoal; $3(0,27 \%)$ problemas financeiros; $2(0,18 \%)$ falta de materiais para o produto; $1(0,09 \%)$ pequena dimensão da empresa; $1(0,09 \%)$ falta de experiência para criar modelos próprios. 
Relativamente às tendências verificadas, $24(2,20 \%)$ responderam que haverá tendência para o crescimento, $11(1,01 \%)$ responderam que haverá tendência para a regressão e $30(2,74 \%)$ responderam que haverá uma constante.

Embora possa não ter que haver uma relação directa com a subcontratação, mas há pelo menos uma ligação empresarial, pelo que apresentamos de seguida algumas empresas com ligação com outras, através da participação no seu capital. Assim, $45(4,12 \%)$ indicaram que tinham ligações com uma empresa, 12 $(1,10 \%)$ indicaram que tinham ligações com duas empresas e $3(0,27 \%)$ indicaram que tinham ligações com três ou mais empresas. Destaca-se que surgiram ligações com setenta e uma empresas, agregando 43 actividades distintas.

\subsection{As vendas}

\subsubsection{Volumes e destinos das vendas}

Do total das $1093^{17}$ empresas, $149(13,63 \%)$ declararam vender por ano entre 500 e 1999 contos, $129(11,80 \%)$ entre 2000-4999. Com vendas até 9999 contos responderam $466(42,63 \%)$ das empresas inquiridas. Entre 10000 e 99999 responderam $291(26,62 \%)$, entre 100000 e 499999 responderam $105(9,61 \%)$.

\section{QUADRO 22}

Dados sobre a Empresa - Volume de vendas / Ano (contos)

(N)

\begin{tabular}{|lrrrrrrrrrrrr|}
\hline & \multicolumn{11}{c}{ CLASSES DA CAE } \\
& 2 & 3 & 3.1 & 3.2 & 3.3 & 3.4 & 3.5 & 3.6 & 3.7 & 3.8 & 3.9 & TOT. \\
\hline-499 & 2 & 96 & 29 & 18 & 18 & 0 & 0 & 3 & 1 & 27 & 0 & 98 \\
$500-1999$ & 0 & 149 & 36 & 11 & 33 & 2 & 1 & 8 & 0 & 57 & 1 & 149 \\
$2000-4999$ & 4 & 125 & 31 & 2 & 38 & 3 & 6 & 9 & 2 & 34 & 0 & 129 \\
$5000-9999$ & 1 & 89 & 29 & 5 & 24 & 4 & 0 & 6 & 5 & 16 & 0 & 90 \\
$10000-19999$ & 4 & 115 & 33 & 9 & 31 & 6 & 0 & 12 & 4 & 20 & 0 & 119 \\
$20000-49999$ & 1 & 111 & 25 & 19 & 31 & 5 & 2 & 14 & 2 & 12 & 1 & 112 \\
$50000-99999$ & 4 & 56 & 17 & 4 & 18 & 3 & 2 & 8 & 0 & 4 & 0 & 60 \\
$100000-499999$ & 4 & 101 & 27 & 26 & 21 & 2 & 4 & 8 & 2 & 11 & 0 & 105 \\
$500000-999999$ & 1 & 14 & 7 & 4 & 0 & 0 & 2 & 0 & 0 & 1 & 0 & 15 \\
$1000000-9999999$ & 0 & 27 & 11 & 7 & 4 & 2 & 1 & 1 & 0 & 1 & 0 & 27 \\
$10000000-99999999$ & 0 & 8 & 4 & 0 & 2 & 0 & 0 & 1 & 0 & 1 & 0 & 8 \\
NÃO RESPOSTA & 9 & 172 & 68 & 23 & 34 & 2 & 6 & 9 & 3 & 21 & 6 & 181 \\
$\quad$ TOTAL-EMPRESAS & 30 & 1063 & 317 & 128 & 254 & 29 & 24 & 79 & 19 & 205 & 8 & 1093 \\
\hline
\end{tabular}


QUADRO 23

Dados sobre a Empresa — Organização de vendas

(N)

\begin{tabular}{|c|c|c|c|}
\hline & 2 & $\begin{array}{c}\text { VISOE S } \\
3\end{array}$ & TOT. \\
\hline 001 & 6 & 214 & 220 \\
\hline 002 & 1 & 184 & 185 \\
\hline 003 & 0 & 3 & 3 \\
\hline 004 & 0 & 11 & 11 \\
\hline 005 & 21 & 515 & 536 \\
\hline 006 & 0 & 74 & 74 \\
\hline 007 & 0 & 6 & 6 \\
\hline 008 & 3 & 89 & 92 \\
\hline 009 & 0 & 4 & 4 \\
\hline 010 & 0 & 3 & 3 \\
\hline 011 & 0 & 4 & 4 \\
\hline 012 & 0 & 26 & 26 \\
\hline 013 & 0 & 13 & 13 \\
\hline 014 & 0 & 7 & 7 \\
\hline 015 & 0 & 15 & 15 \\
\hline 016 & 0 & 1 & 1 \\
\hline 017 & 0 & 3 & 3 \\
\hline 018 & 0 & 6 & 6 \\
\hline 019 & 0 & 8 & 8 \\
\hline 020 & 0 & 2 & 2 \\
\hline 021 & 0 & 4 & 4 \\
\hline 022 & 0 & 2 & 2 \\
\hline 023 & 0 & 1 & 1 \\
\hline 024 & 0 & 1 & 1 \\
\hline NÃO RESPOSTA & 3 & 110 & 113 \\
\hline TOTAL - EMPRESAS & 30 & 1063 & 1093 \\
\hline
\end{tabular}


Entre 500000-999999 responderam 15 (1,37\%). Entre 1000000--9999999 responderam $27(2,47 \%)$. Entre 10000000 e 99999999 responderam $8(0,73 \%)$. Não responderam a esta questão $181(16,56 \%)$ das empresas.

As vendas destinam-se prioritariamente ao mercado interno. Das 1093 empresas inquiridas, $967(88,47 \%)$ não responderam à questão relacionada com a exportação dos produtos fabricados. Das empresas que responderam afirmativamente, $16(1,46 \%)$ indicaram que exportavam toda a sua produção, $28(2,56 \%)$ exportavam entre $75-99 \%, 24(2,20 \%)$ exportavam entre $50-74 \%, 13(1,19 \%)$ exportavam entre $25-49 \%, 45(4,12 \%)$ exportavam até $24 \%$ da sua produção. $O$ destino das exportações por ordem decrescente da frequência das respostas foi: França, Espanha, Alemanha Federal, Inglaterra, Holanda, Bélgica, Suécia, Estados Unidos, Finlândia, Chile.

\subsubsection{Organização das vendas}

Das 1093 empresas inquiridas, $536(49,04 \%)^{18}$ declararam que os clientes vão procurar o produto ao local de fabrico, quer se trate de consumidores, quer de revendedores ou intermediários. No entanto, $220(20,13 \%)$ responderam que procedem à distribuição com viaturas próprias, ao mesmo tempo que utilizam vendedores e agentes para a colocação dos seus produtos. Também 185 (16,93\%) declararam estruturar as suas vendas por encomenda. Responderam possuir lojas próprias e delegações próprias para as vendas $92(8,42 \%)$ dos inquiridos. De igual modo, $74(6,77 \%)$ responderam utilizar comissionistas.

Embora a distribuição de respostas se tivesse processado por 24 escalões diferenciados, constata-se que nestes cinco mencionados se inscrevem as maiores percentagens das respostas. É nas indústrias extractivas que se verifica a maior percentagem relacionada com a procura directa do próprio produto por parte do cliente $21(70,00 \%)$, em relação ao total destas indústrias. Salienta-se, no entanto, que 113 do total das empresas inquiridas $(10,34 \%)$ não responderam a esta questão.

\subsubsection{Promoção de vendas}

\subsubsection{Nas revistas, jornais, rádio, T.V.}

Constata-se que $171(15,65 \%)$ do total das 1093 empresas inquiridas responderam utilizar os jornais para a promoção das vendas. De igual modo, 112 $(10,25 \%)$ responderam utilizar as revistas e os periódicos. Declararam utilizar a rádio $100(9,15 \%)$ empresas e somente $11(1,01 \%)$ responderam recorrer à televisão para a promoção das suas vendas. $O$ fraco recurso à televisão pode estar relacionado com o custo elevado das taxas publicitárias. 


\subsubsection{Outros meios}

De facto mencionaram-se outros meios na promoção das vendas que a seguir destacamos: $76(6,95 \%)$ responderam a utilização de calendários e agendas; 53 $(4,85 \%)$ responderam utilizar catálogos, guias, guiões, almanaques, páginas amarelas, listagens de exportações, roteiros, anuários; $50(4,57 \%)$ responderam utilizar esferográficas, réguas; $15(1,37 \%)$ responderam utilizar placas publicitárias, "placardes", painéis de rua, cartazes, chapas de reclame; 14 (1,28\%) responderam utilizar autocolantes; $13(1,19 \%)$ responderam utilizar programas culturais e recreativos; $12(1,10 \%)$ responderam utilizar feiras e exposições; $11(1,01 \%)$ responderam utilizar panfletos, cartões e igual percentagem declarou utilizar o patrocínio do desporto automóvel para promover as suas vendas.

Verifica-se ainda uma dispersão de respostas por mais dezasseis variados meios, não chegando nenhum deles a atingir $1,00 \%$ das respostas em relação ao total.

\subsubsection{Participação em feiras}

As respostas à questão da participação em feiras distribuíram-se do seguinte modo: $862(78,87 \%)^{19}$ responderam não; $206(18,85 \%)$ responderam sim; 25 $(2,29 \%)$ não responderam a esta questão.

Em relação às feiras participadas, $30(2,74 \%)$ responderam participar na Feira Industrial de Viseu; 29 (2,65\%) na Feira de São Mateus (Viseu); 27 (2,47\%) na F.I.L. (Feira Internacional de Lisboa); $18(1,65 \%)$ na EXPODOURO; $15(1,37 \%)$ na FIAGRIS (Seia); 16 (1,46\%) na EXPONOR (Matosinhos); $11(1,01 \%)$ em

QUADRO 24

Dados sobre a Empresa — Participação em Feiras

(N)

\begin{tabular}{|c|c|c|c|c|c|c|c|c|c|c|c|c|}
\hline & \multicolumn{12}{|c|}{ CLASSES DA CAE } \\
\hline & 2 & 3 & 3.1 & 3.2 & 3.3 & 3.4 & 3.5 & 3.6 & 3.7 & 3.8 & 3.9 & TOT \\
\hline SIM & 6 & 200 & 47 & 44 & 40 & 2 & 11 & 22 & 5 & 27 & 2 & 206 \\
\hline NAO & 23 & 839 & 262 & 82 & 206 & 26 & 12 & 56 & 14 & 175 & 6 & 862 \\
\hline NÃO RESPOSTA & 1 & 24 & 8 & 2 & 8 & 1 & 1 & 1 & 0 & 3 & 0 & 25 \\
\hline TOTAL-EMPRESAS & 30 & 1063 & 317 & 128 & 254 & 29 & 24 & 79 & 19 & 205 & 8 & 1093 \\
\hline
\end{tabular}


feiras nacionais não mencionando o nome concreto; $10(0,91 \%)$ na PORTEX (Porto). Salienta-se, no entanto, que existiram respostas relativas à participação em 104 feiras diferentes. Da análise dos quadros elaborados constata-se a participação em feiras regionais e nacionais e também em feiras internacionais em países como: Espanha, Moçambique, Inglaterra, Suíça, Alemanha, França.

\subsubsection{As vendas e os clientes}

Não surpreende pois que a maior percentagem das respostas no capítulo das vendas tenha sido direccionada para o mercado interno, uma vez que os clientes são sobretudo os nacionais.

Embora à questão relacionada com a caracterização dos clientes fosse permitida mais do que uma resposta, verifica-se que, $828(75,75 \%)^{20}$ das respostas indicaram como clientes Portugal - retalho; 255 (23,33\%) Portugal - indústria; 227 (20,77\%) Portugal — armazéns de importação-exportação e 185 $(16,93 \%)$ Portugal - outros. A venda aos clientes estrangeiros apresenta-se, quantitativamente, menos importante, como se constata no quadro atrás mencionado.

QUADRO 25

Dados sobre a Empresa - Tipo de Clientes

(N)

\begin{tabular}{|c|c|c|c|c|c|c|c|c|c|c|c|c|}
\hline & \multicolumn{12}{|c|}{ CLASSES DA CAE } \\
\hline & 2 & 3 & 3.1 & 3.2 & 3.3 & 3.4 & 3.5 & 3.6 & 3.7 & 3.8 & 3.9 & Tот. \\
\hline PORTUGAL - INDÚSTRIA & 14 & 241 & 25 & 26 & 61 & 21 & 7 & 34 & 10 & 57 & 0 & 255 \\
\hline PORTUGAL - ARM. IMP/EXP & 9 & 218 & 71 & 45 & 47 & 11 & 10 & 12 & 1 & 16 & 5 & 227 \\
\hline PORTUGAL - RETALHO & 21 & 807 & 252 & 72 & 192 & 22 & 18 & 67 & 13 & 169 & 2 & 828 \\
\hline PORTUGAL - OUTROS & 3 & 182 & 60 & 16 & 33 & 11 & 7 & 16 & 5 & 32 & 2 & 185 \\
\hline ESTRANG. - INDÚSTRIA & 1 & 45 & 6 & 14 & 20 & 1 & 1 & 2 & 0 & 1 & 0 & 46 \\
\hline ESTRANG. - ARM. IMP/EXP & 2 & 58 & 11 & 24 & 13 & 1 & 4 & 2 & 0 & 3 & 0 & 60 \\
\hline ESTRANG. - RETALHO & 2 & 28 & 7 & 10 & 8 & 0 & 1 & 0 & 0 & 2 & 0 & 30 \\
\hline ESTRANG. - OUTROS & 1 & 19 & 3 & 6 & 4 & 1 & 2 & 1 & 0 & 2 & 0 & 20 \\
\hline NÃO RESPOSTA & 1 & 20 & 9 & 0 & 5 & 0 & 0 & 1 & 0 & 5 & 0 & 21 \\
\hline TOTAL-EMPRESAS & 30 & 1063 & 317 & 128 & 254 & 29 & 24 & 79 & 19 & 205 & 8 & 1093 \\
\hline
\end{tabular}




\section{OS ACTORES ECONÓMICOS, POLÍTICOS, SOCIAIS E CULTURAIS. LOCAIS E A IMPLEMENTAÇÃO DA INDÚSTRIA}

Tal como era em Águeda e Arganil ${ }^{21}$, também no distrito de Viseu se constata a intermediação e a mediação de um conjunto de actores na implantação da indústria, embora com as suas especificidades. Neste distrito, a AIRV nasceu no início da década de 1980 , como resultante da consciencialização de que "juntos podemos vencer mais facilmente as barreiras que nos cercam e proporcionar a vida de outros para investir na nossa região", como nos revelou um dos seus fundadores. Esta associação, na primeira fase (1982-85), funcionou mais como grupo de pressão junto dos orgãos da administração central, regional e local.

A partir de 1987-88 constata-se uma tendência para passar a uma acção mais directa junto dos empresários (associados ou não). Assim, começa a contratar técnicos especializados para o apoio na elaboração de projectos aos associados (quer ao nível de implantação de novas indústrias, quer em aç̧ões de formação profissional, quer na organização de feiras e exposições por sua livre iniciativa (madeiras, informática), visando dinamizar o tecido empresarial, por um lado, e obter receitas, por outro, de molde a reduzir a sua sobrevivência dos subsídios (quer estatais, quer de outras proveniências).

Por outro lado, passou a desempenhar um papel qualificado junto de outros actores, por exemplo, Universidades e Institutos Politécnicos regionais, visando obter uma diversidade de novos cursos e de novas infra-estruturas ligadas à investigação-acção, como seja a criação do Parque Tecnológico.

Além disso, procura criar condições para a organização de visitas de estudo e missões ao estrangeiro dirigidas aos empresários associados, ao mesmo tempo que acolhe os potenciais investidores nacionais e estrangeiros que mostrem interesse em conhecer a região.

Outro dos organismos que actuam como grupo de pressão, para incentivar investimentos públicos e privados, é a Associação Comercial de Viseu. Sem o dinamismo e sem a determinação da $\mathrm{AIRV}^{22}$, contudo procura constituir mais um elemento influenciador de decisões, quer junto de entidades públicas, quer junto de entidades privadas, no sentido de atrair os investimentos, quer a nível local, quer regional.

Um papel relevante na implantação das indústrias tem sido exercido pelas autarquias locais. Desde a aquisição e cedência de terrenos, a preço simbólico, para a implantação das indústrias (quer nos chamados parques industriais, quer em casos pontuais em que os empresários decidem iniciar ou ampliar as indústrias existentes), quer na comparticipação nos custos de instalação (infra-estruturas rodoviárias, eléctricas, construção de edifícios), quer na implementação de subsídios por postos de trabalho criados com os novos investimentos.

Como casos mais significativos de captação de apoio ao investimento salientamos as autarquias dos concelhos de Viseu (que já vai no terceiro parque industrial), Oliveira de Frades, Tondela, Mangualde e Vouzela. 
Em Oliveira de Frades passámos de um concelho onde a indústria era praticamente inexistente há 12 anos, com uma mão-de- obra excedentária nas actividades agrícolas, para um concelho onde actualmente se verifica uma escassez de mão-de-obra ${ }^{23}$, devido à implantação das indústrias, devido sobretudo à mediação exercida pela Câmara Municipal.

O Governo Civil também tem desempenhado um papel de mediação, sobretudo entre o Governo central e as autarquias, associações empresariais e empresários individuais, proporcionando entrevistas e deslocações de membros do Governo, sobretudo dos mais directamente relacionados com os apoios aos investimentos. Neste momento e sob o patrocínio do actual Governador Civil está a ser ultimada a elaboração (com estagiários da licenciatura em Gestão e Desenvolvimento Social da Universidade Católica) de um estudo monográfico inter-sectorial do distrito, tendo em vista relevar as suas potencialidades, de molde a atrair potenciais investidores.

A instalação de delegações de organismos oficiais vocacionados para o apoio ao investimento e à criação de emprego (IAPMEI, Instituto de Emprego e Formação Profissional, entre outras, bem como a abertura de dependências bancárias) (neste momento há representação de 18 bancos) e de sociedades de leasing. Também facilita o diálogo para o ressurgimento de novos investidores.

Mencionamos o papel dos deputados pela acção desenvolvida sobretudo como poderoso grupo de pressão, junto dos orgãos governamentais atrás mencionados, sendo também destacada a sua influência (embora não publicamente) na aprovação de projectos privados de investimento.

As instituições de ensino superior (Universidade Católica Portuguesa e o Instituto Politécnico) têm procurado criar novos cursos, em consonância com as sugestões e recomendações das associações empresariais, autarquias locais e outros actores locais. Por outro lado, a Universidade Católica (Curso de Gestão e Desenvolvimento Social) fundou, em 1988, uma associação de apoio ao Instituto Universitário de Desenvolvimento e Promoção Social (I.U.D.P.S.) de que são membros empresas, bancos, instituições de solidariedade social com sede local, regional e até mesmo nacional. Entre outros objectivos, destacam-se: a ligação entre as actividades do I.U.D.P.S. e a comunidade, formação e investigação e a criação de infra-estruturas de apoio tecnológico aos diversos sectores da actividade económica e à elaboração de projectos de lançamento de acções que contribuam para a modernização da sociedade portuguesa, em particular das empresas, autarquias, cooperativas, associações e organismos públicos.

Esta associação de apoio tem desenvolvido estudos de caracterização sócioeconómica por solicitação de autarquias, empresas, bem como programas de formação profissional e seminários sobre temas de desenvolvimento regional.

Temos também a destacar o papel da Misericórdia de Viseu e da Diocese, que têm cedido gratuitamente terrenos e imóveis para a instalação da Universidade Católica, de molde a criar condições para a abertura dos ramos de engenharia no centro regional de Viseu, para além dos cursos de letras e de gestão já existentes. 


\section{NOTAS}

1. Eng. ${ }^{\circ}$ Jorge Oliveira Dias.

2. Vidé Alberto Martinho, O tecido industrial da regiäo de Viseu, Viseu, AIRV, 1992.

3. Ver o quadro 11.

4. Ver o quadro 12.

5. Ver o quadro 13.

6. Utilizamos a classificação das actividades económicas do I.N.E. Ver a classificação das actividades económicas portuguesas por ramos de actividade, I.N.E., série 19 , normas $n .^{\circ} 6$.

7. Ver o quadro 14.

8. Ver o quadro 15.

9. Ver o quadro 16.

10. Ver o quadro 17.

11. Ver o quadro 18.

12. Ver o quadro 19.

13. Ver o quadro 20. A questão relativa ao quadro 20 permitiu mais do que uma resposta.

14. A esta questão foi permitida mais do que uma resposta.

15. A esta questão foi permitida mais do que uma resposta.

16. Ver o quadro 21.

17. Ver o quadro 22.

18. Ver o quadro 23. A esta questão foi permitida mais do que uma resposta.

19. Ver o quadro 24.

20. Ver o quadro 25.

21. José Reis, Os espaços da indústria, Porto, Edições afrontamento, 1992, p. 203-260.

22. Apenas em 1991 deu início à contratação de técnicos qualificados, procurando dinamizar junto dos associados a implementação do Programa de Modernização do comércio.

23. Informações fornecidas por um empresário local e pela Câmara Municipal. 


\section{BIBLIOGRAFIA}

ALMEIDA, João Ferreira, 1990, "Valores e representações sociais" (Portugal-Os próximos 20 anos, VIII vol.), Lisboa, Fundação Calouste Gulbenkian.

COSTA, António Firmino e outros, 1984, Artes de Ser e de Fazer no Quotidiano Operário, Lisboa, CIES/SCTE.

DUARTE, Isabel, 1988, "Relações sócio-económicas numa região industrial em transformação - o caso da Covilhã", Sociologia-problemas e práticas, n. ${ }^{\circ 5}$, Outubro, 127-148.

FERRÃO, João, 1987, "Indústria e território: breve história de uma união feliz", Revista Crítica de Ciências Sociais, $\mathrm{n}^{\circ}$ 22, Abril.

GASPAR, Jorge, 1988, "Ocupação e Organização do Espaço-Retrospectiva e Tendências" (Portugal-Os próximos 20 anos, VI vol.), Lisboa, Fundação Calouste Gulbenkian.

GUERREIRO, Maria das Dores, 1989, "A família e a empresa", in Sociologia-problemas $e$ práticas, $n .{ }^{\circ}$, Maio, 23-32.

JICA (Japan International Cooperation Agency) and ICEP, 1992, "Summary papers for convergence meeting on industrial development promotion study of Aveiro-Viseu Region in the portuguese republic, Lisboa.

LOPES, Ernâni Rodrigues e outros, 1989, Portugal, o desafio dos anos 90, Lisboa, Editorial Presença.

LOURENÇO, Nelson, 1990, Família Rural e Indústria, Lisboa, EDitora Fragmentos.

MARTINHO, Alberto, 1977, As voltas que o fio dá, Guarda, Ed. do autor.

MARTINHO, Alberto, 1992, O tecido industrial da região de Viseu, Viseu, AIRV.

MÓNICA, Maria Filomena, 1987, "Capitalistas e industrais (1870-1914)", Análise Social, vol. XXIII (99)-5. ${ }^{\circ}, 819-863$.

MÓNICA, Maria Filomena, 1990, Os grandes patrões da indústria portuguesa, Lisboa, Publicações Dom Quixote.

PINTO, José Madureira e QUEIRÓS, Maria Cidália, 1990, "Lugares de classe e contextos de aprendizagem social", Cadernos de Ciências Sociais, n. ${ }^{\circ}$ 8/9, Fevereiro, 131-144.

REIS, José, 1987, "Os espaços da industrialização", Revista Crítica de Ciências Sociais, n. ${ }^{22}$, Abril, 13-32.

REIS, José, 1992, Os espaços industriais, Porto, Edições afrontamento.

RODRIGUES, Maria João, 1988, O sistema de emprego em Portugal - crise e mutação, Lisboa, Publicações Dom Quixote. 